\title{
Study of Knowledge, Attitude, and Practice among Epilepsy Patients in North India
}

\author{
Arshdeep Kaur Sethi ${ }^{1}$ Vineeta Singh ${ }^{1}$ Rameshwar Nath Chaurasia ${ }^{1}$ Deepika Joshi ${ }^{1}$ \\ Abhishek Pathak ${ }^{1}$ Shivani Rath ${ }^{1}$ Ashutosh Mishra ${ }^{1}$ Vijay Nath Mishra ${ }^{1}$ \\ ${ }^{1}$ Department of Neurology, Institute of Medical Sciences, Banaras \\ Address for correspondence Vijay Nath Mishra, MBBS, MD, DM, \\ Hindu University, Varanasi, Uttar Pradesh, India \\ Department of Neurology, Institute of Medical Sciences, \\ Banaras Hindu University, Varanasi 221005, Uttar Pradesh, India \\ (e-mail: vnmishra_2000@yahoo.com).
}

J Neurosci Rural Pract 2020;11:278-285

\begin{abstract}
Background Religious and sociocultural beliefs influence the nature of treatment and care received by people with epilepsy.

Objective This study aimed to study knowledge, attitude, and practice (KAP) among epilepsy patients in north India.

Materials and Methods In this study, 201 patients attending the outpatient and inpatient services of the neurology department of Sir Sunderlal Hospital, Banaras Hindu University, were asked to fill a questionnaire comprising 25 questions assessing the KAPs in English or Hindi, whichever the patient was proficient with. The same questionnaire was also given to 200 patients without epilepsy for the control group. Responses were recorded as yes/no/do not know.

Results Approximately, $67 \%$ of the patients consisted of a young population, of which $64.7 \%$ were males and $35.3 \%$ were females. Around $25.9 \%$ of patients had studied up to 10 th class, $96.5 \%$ of patients had heard of epilepsy, and $89.05 \%$ thought it was treatable by modern drugs. Out of all patients, $80.1 \%$ of patients believed that epilepsy was not contagious, $87.6 \%$ believed that they can work, $93.5 \%$ believed that they can marry, $66.5 \%$ did not feel discriminated by batchmates, and $78.5 \%$ did not feel discriminated by teachers. Of all patients, $41.8 \%$ said that they would disclose the epi-

Keywords

- epilepsy

- knowledge

- attitude

- practice leptic condition of their daughters before marriage and $96.01 \%$ knew epilepsy patients should be taken to hospital.

Conclusion Poor knowledge, negative attitude, and malpractices regarding epilepsy are still prevalent in North India. Epilepsy patients have better knowledge than normal people about this disease. There is still a need to educate people about epilepsy.
\end{abstract}

\section{Introduction}

In 2005, the International League against Epilepsy (ILAE) and International Bureau for Epilepsy (IBE) defined epilepsy as a disorder of the brain characterized by an enduring predisposition to generate epileptic seizures and with the cognitive, neurobiological, psychological, and social consequences of this condition. ${ }^{1}$ Epilepsy affects nearly 50 million people worldwide. Epilepsy accounts for $1 \%$ of the global burden of disease; however, $80 \%$ of the burden of epilepsy is in developing countries. ${ }^{2}$ The annual incidence of epilepsy in India is approximately 40 to 50 per 100,000 per year. Out of 10 million epileptics in India, 3 million have drug-resistant epilepsy. ${ }^{3}$ In India, people still consider epilepsy to be a stigma. Improving awareness and understanding about a disease can help in its prophylaxis and treatment. Due to the lack of this awareness, there is a large treatment gap among epilepsy patients. ${ }^{4}$ Therefore, knowledge about the awareness and attitudes of the people toward epilepsy is necessary, as misconceptions about this disease affect the quality of life of the patients. 


\section{Materials and Methods}

This study was conducted in the Department of Neurology, Institute of Medical Sciences, Banaras Hindu University, Varanasi, from October 2016 to July 2018.

\section{Study Design}

It was a hospital-based, cross-sectional study in which 201 patients with epilepsy attending the outpatient and inpatient services of Sir Sunderlal Hospital, Banaras Hindu University, Varanasi, were asked to fill a questionnaire comprising 25 questions assessing the knowledge, attitude, and practices (KAPs) in English or Hindi, whichever the patients were proficient with. The same questionnaire was also given to 200 patients without epilepsy attending the outpatient and inpatient services of Sir Sunderlal Hospital, Banaras Hindu University, Varanasi, for the control group. The responses were recorded as "yes," "no," and "do not know." The questionnaire was taken from a KAP study done by Gourie Devi et al in Delhi which was published in Neurology Asia in $2010 .^{5}$

\section{Inclusion Criteria}

1. Patients aged $>18$ years.

2. Should be able to understand, read, speak or write in English/Hindi.

3. Capable of answering the questions either in written form or by interview.

\section{Exclusion Criteria}

1. Patients with a history of nonepileptic seizures.

2. Seizures related to drugs, alcohol, or acute medical illness.

3. Patients whose clinical and laboratory data do not allow a clear determination of whether or not the patient has epilepsy.

4. Patients with a history of pancreatitis, nephrolithiasis, or hypercalciuria, or clinically significant laboratory abnormalities suggestive of metabolic imbalance.

\section{Statistical Analysis}

Categorical data were presented as frequencies and percentages. Pearson's Chi-square test was used to compare proportions for the two groups of respondents. A $p$-value $<0.05$ was deemed statistically significant.

\section{Results}

More men than women thought that children with epilepsy can study (108 compared with 49) and would allow their child to play with epilepsy patients (112 compared with 53). More number of females $(n=37,52.1 \%)$ felt discriminated by their spouses as compared with males ( $n=47$ i.e., $36.2 \%$; - Table 1. Among the patients with epilepsy, $96.5 \%(n=193)$ had heard of epilepsy, $87.5 \%$ knew that it was a brain disorder, $81.1 \%$ knew that it was not a mental disease, $81.59 \%$ knew that it was not hereditary, $71.14 \%$ knew that it was not due
Table 1 Demographic details of epileptic patients

\begin{tabular}{|c|c|}
\hline Particulars (\%) & $n(\%)$ \\
\hline \multicolumn{2}{|l|}{ Age (y) } \\
\hline Up to 30 & 136(67.67) \\
\hline $31-50$ & $42(20.89)$ \\
\hline More than 50 & $23(11.44)$ \\
\hline \multicolumn{2}{|l|}{ Gender } \\
\hline Male & $130(64.7)$ \\
\hline Female & $71(35.3)$ \\
\hline \multicolumn{2}{|l|}{ Marital status } \\
\hline Married & 107(53.2) \\
\hline Unmarried & $94(46.8)$ \\
\hline \multicolumn{2}{|c|}{ Regional distribution } \\
\hline Rural & $134(66.7)$ \\
\hline Urban & $67(33.3)$ \\
\hline \multicolumn{2}{|l|}{ Occupation } \\
\hline Students & $77(38.3)$ \\
\hline Employed & $64(31.8)$ \\
\hline Farmers & $18(9)$ \\
\hline Housewives & $39(19.4)$ \\
\hline Unemployed & $3(1.5)$ \\
\hline \multicolumn{2}{|l|}{ Education } \\
\hline Below 8th & $23(11.4)$ \\
\hline Up to 8th & $29(14.4)$ \\
\hline Up to 10th & $52(25.9)$ \\
\hline Up to 12 th & $73(36.3)$ \\
\hline Graduation & $23(11.4)$ \\
\hline
\end{tabular}

to supernatural causes, $80.09 \%$ knew that it was not contagious, $66.17 \%$ knew that it was not due to ancestors' sins, and $74.13 \%$ knew that faith healing is useless. In the study group, $89.05 \%$ believed that epilepsy is treatable by modern drugs, and $40.3 \%$ knew that ayurvedic drugs were useless. Of all the patients, 78.11\% patients believed that epilepsy patients can study, $81.6 \%$ would allow their children to play with epilepsy patients, $92.3 \%$ believed that these patients can play, $87.6 \%$ thought that they can do jobs, $93.5 \%$ believed that they can marry, and $86.5 \%$ believed that they can have children. However, $50.8 \%$ of patients felt discriminated by their batchmates, $29.85 \%$ by their teachers, and $19.9 \%$ by their spouses. Of all the patients, $56.72 \%$ did not want to reveal the epilepsy condition of their daughter and $53.23 \%$ would want to hide the fact that their son has epilepsy before marriage. As far as practices were concerned, $78.61 \%$ of people knew that handing keys to a seizing patient was useless, $66.67 \%$ knew that sprinkling water was useless, and $74.63 \%$ knew branding was not helpful. In the test group, $96 \%$ of people wanted to take a seizing patient to a hospital.

Among the people without epilepsy, $96 \%$ had heard of epilepsy, $67 \%$ knew that it was a brain disorder, $30.5 \%$ knew that it was not a mental disease, $46.5 \%$ knew that it was not hereditary, $51 \%$ knew that it was not due to supernatural causes, $70.5 \%$ knew that it was not contagious, and 50.5\% knew that it was not due to ancestors' sins and $62.5 \%$ knew 
that faith healing was useless. In the control group, 90.5\% believed epilepsy is treatable by modern drugs and $13 \% \mathrm{knew}$ ayurvedic drugs were useless, $92 \%$ patients believed that epilepsy patients can study, $72 \%$ would allow their children to play with epilepsy patients, $90 \%$ believed that these patients can play, $79 \%$ thought that they can do jobs, $85.5 \%$ believed that they can marry, and $61 \%$ believed that they can have children. However, $21.5 \%$ of children felt such patients are discriminated by their batchmates, $10.5 \%$ by their teachers, and $15.5 \%$ by their spouses. In the control group, $60.5 \% \mathrm{did}$ not want to reveal the epilepsy condition of their daughter and $41.5 \%$ would want to hide the fact that their son has epilepsy before marriage. As far as practices were concerned, $66.5 \%$ of people knew that handing keys to a seizing patient was useless, $58.5 \%$ knew that sprinkling water was useless, and $60 \%$ knew that branding was not helpful. Also, $96.5 \%$ of people wanted to take a seizing patient to a hospital. The difference in the KAP between the two groups is given in

- Tables 2-4.

\section{Discussion}

Similar to the findings by Gourie Devi et $a l,{ }^{5}$ the maximum number of patients were $<30$ years of age $(67.7 \%)$, males were more (64.7\%) than females (35.3\%), rural patients were more than urban (66.7\% compared with $33.3 \%)$, and most of the patients were students (38.3\%). In this study, male patients with epilepsy had a better attitude toward epileptic patients as compared with females. More males in the study group thought that a child with epilepsy can study (83\%), would allow their child to play with a child having epilepsy (86\%), and knew that branding in epilepsy was useless (64\%). More females than males felt that they were discriminated against by their spouses (79\%). It has been found in some studies that people belonging to urban areas have better knowledge and attitude toward epilepsy as compared with the rural area but no significant difference was found in our study. ${ }^{6,7}$

The maximum number of patients (73 or $25.9 \%$ ) had studied up to 12 th standard. Of all the patients, $11.4 \%$ had studied up to graduate level and $11.4 \%$ of patients had studied below eighth class. Also, in the study by Gourie Devi et al, the largest group was of patients who had studied up to school (64\%). ${ }^{5}$ The number of graduate people was more in our study (11\%) as compared with $5 \%$ seen in the study by Gourie Devi et al. ${ }^{5}$ It has been found that a higher level of education is associated with better knowledge and attitude toward epilepsy. In a study among Malaysian Chinese people, positive responses were mainly acquired from respondents with secondary schooling and above. ${ }^{5}$

Table 2 Knowledge among patients with epilepsy and without epilepsy

\begin{tabular}{|c|c|c|c|c|c|c|c|}
\hline \multirow[t]{3}{*}{ Questions } & \multicolumn{6}{|c|}{ Answer: $n(\%)$} & \multirow{3}{*}{$\begin{array}{l}\text { Chi-square score } \\
p \text {-Value }\end{array}$} \\
\hline & \multicolumn{2}{|c|}{ Yes } & \multicolumn{2}{|c|}{ No } & \multicolumn{2}{|c|}{ Do not know } & \\
\hline & $\begin{array}{l}\text { Patients } \\
\text { without } \\
\text { epilepsy }\end{array}$ & $\begin{array}{l}\text { Patients } \\
\text { with } \\
\text { epilepsy }\end{array}$ & $\begin{array}{l}\text { Patients } \\
\text { with } \\
\text { epilepsy }\end{array}$ & $\begin{array}{l}\text { Patients } \\
\text { with } \\
\text { epilepsy }\end{array}$ & $\begin{array}{l}\text { Patients } \\
\text { without } \\
\text { epilepsy }\end{array}$ & $\begin{array}{l}\text { Patients } \\
\text { with } \\
\text { epilepsy }\end{array}$ & \\
\hline $\begin{array}{l}\text { Have you heard } \\
\text { about epilepsy? }\end{array}$ & $192(96)$ & 193 (96.5) & $8(4)$ & $7(3.5)$ & 0 & 0 & $\begin{array}{l}\chi^{2}=0.006 \\
p=0.79\end{array}$ \\
\hline $\begin{array}{l}\text { Is epilepsy a } \\
\text { brain disorder? }\end{array}$ & $134(67)$ & $176(87.5)$ & $49(24.5)$ & $16(8)$ & $17(8.5)$ & $9(4.5)$ & $\begin{array}{l}\chi^{2}=24.9 \\
p=0.001\end{array}$ \\
\hline $\begin{array}{l}\text { Is epilepsy a } \\
\text { mental disease? }\end{array}$ & $108(54)$ & $20(9.95)$ & $60(30.5)$ & $163(81.1)$ & $31(15.5)$ & $18(8.95)$ & $\begin{array}{l}\chi^{2}=111.5 \\
p=0.01\end{array}$ \\
\hline $\begin{array}{l}\text { Is epilepsy a } \\
\text { hereditary } \\
\text { disorder? }\end{array}$ & $55(27.5)$ & $26(12.93)$ & $93(46.5)$ & 164 (81.59) & $52(26)$ & $11(5.47)$ & $\begin{array}{l}\chi^{2}=56.67 \\
p=0.001\end{array}$ \\
\hline $\begin{array}{l}\text { Is epilepsy due } \\
\text { to supernatural } \\
\text { powers? }\end{array}$ & $75(37.5)$ & $57(28.36)$ & $102(51)$ & $143(71.14)$ & $23(11.5)$ & $1(0.5)$ & $\begin{array}{l}\chi^{2}=29.48 \\
p=0.001\end{array}$ \\
\hline $\begin{array}{l}\text { Is epilepsy } \\
\text { contagious? }\end{array}$ & $53(26.5)$ & $26(12.9)$ & $141(70.5)$ & 161 (80.09) & $6(3)$ & $14(6.96)$ & $\begin{array}{l}\chi^{2}=13.47 \\
p=0.001\end{array}$ \\
\hline $\begin{array}{l}\text { Is it due to sins } \\
\text { of patient/ } \\
\text { ancestors? }\end{array}$ & $76(38)$ & $63(31.34)$ & $101(50.5)$ & $133(66.17)$ & $23(11.5)$ & $5(2.4)$ & $\begin{array}{l}\chi^{2}=17.16 \\
p=0.001\end{array}$ \\
\hline $\begin{array}{l}\text { Is epilepsy } \\
\text { treatable with } \\
\text { modern drugs? }\end{array}$ & $181(90.5)$ & $179(89.05)$ & $7(3.5)$ & $17(8.45)$ & $12(6)$ & $5(2.5)$ & $\begin{array}{l}\chi^{2}=7.057 \\
p=0.001\end{array}$ \\
\hline $\begin{array}{l}\text { Is epilepsy } \\
\text { treatable with } \\
\text { Ayurvedic } \\
\text { medicine? }\end{array}$ & 151 (75.5) & 90 (44.78) & $26(13)$ & $81(40.3)$ & $23(11.5)$ & $30(14.92)$ & $\begin{array}{l}\chi^{2}=44.63 \\
p=0.0293\end{array}$ \\
\hline $\begin{array}{l}\text { Can faith healers } \\
\text { treat epilepsy? }\end{array}$ & $68(34)$ & $35(17.41)$ & $125(62.5)$ & $149(74.13)$ & $7(3.5)$ & $17(8.46)$ & $\begin{array}{l}\chi^{2}=16.83 \\
p=0.002\end{array}$ \\
\hline
\end{tabular}


Table 3 Attitude toward epilepsy among patients with epilepsy and without epilepsy

\begin{tabular}{|c|c|c|c|c|c|c|c|}
\hline \multirow[t]{3}{*}{ Questions } & \multicolumn{6}{|c|}{ Answer: $n(\%)$} & \multirow{3}{*}{$\begin{array}{l}\text { Chi-square } \\
\text { score } \\
p \text {-Value }\end{array}$} \\
\hline & \multicolumn{2}{|c|}{ Yes } & \multicolumn{2}{|c|}{ No } & \multicolumn{2}{|c|}{ Don't know } & \\
\hline & $\begin{array}{l}\text { Patients } \\
\text { without } \\
\text { epilepsy }\end{array}$ & $\begin{array}{l}\text { Patients } \\
\text { with } \\
\text { epilepsy }\end{array}$ & $\begin{array}{l}\text { Patients with } \\
\text { epilepsy }\end{array}$ & $\begin{array}{l}\text { Patients } \\
\text { with } \\
\text { epilepsy }\end{array}$ & $\begin{array}{l}\text { Patients } \\
\text { without } \\
\text { epilepsy }\end{array}$ & $\begin{array}{l}\text { Patients } \\
\text { with } \\
\text { epilepsy }\end{array}$ & \\
\hline $\begin{array}{l}\text { Can a child with } \\
\text { epilepsy study? }\end{array}$ & $184(92)$ & $157(78.11)$ & $42(20.90)$ & $14(7)$ & $2(1)$ & $2(0.99)$ & $\begin{array}{l}\chi^{2}=16.83 \\
p=0.002\end{array}$ \\
\hline $\begin{array}{l}\text { Will you allow } \\
\text { your child to } \\
\text { play with a child } \\
\text { with epilepsy? }\end{array}$ & $144(72)$ & $164(81.6)$ & $37(18.4)$ & $47(23.5)$ & $9(4.5)$ & 0 & $\begin{array}{l}\chi^{2}=8.76 \\
p=0.003\end{array}$ \\
\hline $\begin{array}{l}\text { Is the child } \\
\text { discriminated by } \\
\text { school-mates? }\end{array}$ & $43(21.5)$ & $102(50.8)$ & $95(45.77)$ & $133(66.5)$ & $24(12)$ & 4 (1.99) & $\begin{array}{l}\chi^{2}=44.62 \\
p=0.001\end{array}$ \\
\hline $\begin{array}{l}\text { Is the child } \\
\text { discriminated by } \\
\text { teachers? }\end{array}$ & $21(10.5)$ & $60(29.85)$ & $134(66.67)$ & 157 (78.5\%) & $22(11)$ & $7(3.48)$ & $\begin{array}{l}\chi^{2}=8.89 \\
p=0.011\end{array}$ \\
\hline $\begin{array}{l}\text { Can a child with } \\
\text { epilepsy play } \\
\text { games? }\end{array}$ & $180(90)$ & $184(92.53)$ & $15(7.46)$ & $15(7.5)$ & $5(2.5)$ & 1 & $\begin{array}{l}\chi^{2}=2.71 \\
p=0.237\end{array}$ \\
\hline $\begin{array}{l}\text { Can a person } \\
\text { with epilepsy } \\
\text { take up a job? }\end{array}$ & $158(79)$ & $176(87.6)$ & $24(11.94)$ & $24(12)$ & $18(9)$ & $1(0.5)$ & $\begin{array}{l}\chi^{2}=16.17 \\
p=0.03\end{array}$ \\
\hline $\begin{array}{l}\text { Can a person } \\
\text { with epilepsy } \\
\text { marry? }\end{array}$ & $171(85.5)$ & $188(93.5)$ & $9(4.48)$ & $19(9.5)$ & $10(5)$ & 4 (1.99) & $\begin{array}{l}\chi^{2}=6.94 \\
p=0.03\end{array}$ \\
\hline $\begin{array}{l}\text { Will you reveal } \\
\text { about the } \\
\text { epilepsy of your } \\
\text { daughter before } \\
\text { marriage? }\end{array}$ & $51(25.5)$ & $84(41.79)$ & $114(56.72)$ & $121(60.5)$ & $28(14)$ & $3(1.49)$ & $\begin{array}{l}\chi^{2}=26.26 \\
p=0.001\end{array}$ \\
\hline $\begin{array}{l}\text { Will you reveal } \\
\text { about the } \\
\text { epilepsy of } \\
\text { your son before } \\
\text { marriage? }\end{array}$ & $84(42)$ & $91(45.27)$ & $107(53.23)$ & $83(41.5)$ & $33(16.5)$ & $3(1.49)$ & $\begin{array}{l}\chi^{2}=28.30 \\
p=0.001\end{array}$ \\
\hline $\begin{array}{l}\text { Can a person } \\
\text { with epilepsy } \\
\text { have children? }\end{array}$ & $162(61)$ & $174(86.57)$ & $10(4.97)$ & $13(6.5)$ & $25(12.5)$ & $17(8.46)$ & $\begin{array}{l}\chi^{2}=2.341 \\
p=0.310\end{array}$ \\
\hline $\begin{array}{l}\text { Are you } \\
\text { discriminated } \\
\text { by spouse? }\end{array}$ & $31(15.5)$ & 40 (19.9) & $119(59.20)$ & 139 (69.5) & $30(15)$ & $42(20.89)$ & $\begin{array}{l}\chi^{2}=4.68 \\
p=0.95\end{array}$ \\
\hline
\end{tabular}

In our study, 96.5\% ( $n=193)$ patients had heard about epilepsy. In the control group, 96\% (192 patients) had heard of epilepsy which was similar to the study group. The persons who had heard of epilepsy were $94 \%$ in a study by Gourie Devi et $\mathrm{al}^{5}$ and $99 \%$ in a study by Radhakrishnan et $\mathrm{al}^{4}$ which was similar to our study. In our study group, 176 patients (87.5\%) thought epilepsy to be a brain disorder. Only 134 patients in the control group (67\%) considered it to be a brain disorder, which was lower than the study group. In the study by Gourie Devi et al, this number was lower as only $55 \%$ knew that it was an organic brain disorder. ${ }^{5}$ A study by Radhakrishnan et al done among the general population in Kerala with a high literacy rate found that $68 \%$ of the respondents believed that it was a brain disease, which matched the findings in our control group without epilepsy. ${ }^{4}$ Patients with epilepsy had a better knowledge of this being a neurological problem. Surekha and Surekha in 2000 found that $23 \%$ believed that epilepsy was a type of disease of the brain, which increased to $57 \%$ after 4 years when another survey was performed in the same population after health education regarding epilepsy was provided to the patients. ${ }^{8}$ A study conducted in Bundelkhand found that only $58 \%$ thought epilepsy was a brain disorder. ${ }^{9}$ In our study, 163 patients (80.6\%) considered epilepsy not to be a mental disease in the study group, whereas only 61 patients (30.5\%) in the control group thought the same, which was lower as compared with the study group. Among 220 patients with epilepsy in Ohio, United States, 30\% considered it to be a 
Table 4 Practice regarding epilepsy in patients with epilepsy and without epilepsy

\begin{tabular}{|c|c|c|c|c|c|c|c|}
\hline \multirow[t]{3}{*}{ Questions } & \multicolumn{6}{|c|}{ Answer: $n(\%)$} & \multirow{3}{*}{$\begin{array}{l}\text { Chi-square score } \\
p \text {-Value }\end{array}$} \\
\hline & \multicolumn{2}{|c|}{ Yes } & \multicolumn{2}{|c|}{ No } & \multicolumn{2}{|c|}{ Don't know } & \\
\hline & $\begin{array}{l}\text { Patients } \\
\text { without } \\
\text { epilepsy }\end{array}$ & $\begin{array}{l}\text { Patients } \\
\text { with } \\
\text { epilepsy }\end{array}$ & $\begin{array}{l}\text { Patients } \\
\text { with } \\
\text { epilepsy }\end{array}$ & $\begin{array}{l}\text { Patients } \\
\text { with } \\
\text { epilepsy }\end{array}$ & $\begin{array}{l}\text { Patients } \\
\text { without } \\
\text { epilepsy }\end{array}$ & $\begin{array}{l}\text { Patients } \\
\text { with } \\
\text { epilepsy }\end{array}$ & \\
\hline $\begin{array}{l}\text { During an epileptic } \\
\text { attack will you put } \\
\text { keys in the hands of } \\
\text { patients? }\end{array}$ & $57(26.5)$ & $40(19.9)$ & $158(78.61)$ & $158(78.61)$ & $10(5)$ & $3(1.49)$ & $\begin{array}{l}\chi^{2}=8.89 \\
p=0.011\end{array}$ \\
\hline $\begin{array}{l}\text { During an epileptic } \\
\text { attack will you make } \\
\text { the patient smell a } \\
\text { shoe? }\end{array}$ & $77(38.5)$ & $66(32.83)$ & $134(66.67)$ & $134(66.67)$ & $7(3.5)$ & $1(0.5)$ & $\begin{array}{l}\chi^{2}=6.63 \\
p=0.03\end{array}$ \\
\hline $\begin{array}{l}\text { During an epileptic } \\
\text { attack will you take the } \\
\text { patient to hospital? }\end{array}$ & $193(96.5)$ & $193(96.01)$ & $8(3.98)$ & $8(3.98)$ & 0 & 0 & $\begin{array}{l}\chi^{2}=0.06 \\
p=0.79\end{array}$ \\
\hline $\begin{array}{l}\text { Is branding useful in } \\
\text { epilepsy? }\end{array}$ & $5(2.5)$ & $9(4.48)$ & $150(74.63)$ & $150(74.63)$ & $75(37.5)$ & $42(20.89)$ & $\begin{array}{l}\chi^{2}=13.7 \\
p=0.01\end{array}$ \\
\hline
\end{tabular}

mental disorder. ${ }^{10}$ Similar were the findings in Delhi, Kerala, and Nigeria. ${ }^{4,10,11}$ In Bundelkhand, 400 people visiting the OPD of Maharani Laxmibai College were subjected to KAP study and $68 \%$ of patients in this study believed that epilepsy was a mental disorder. ${ }^{9}$ A study done among 191 college students in Canada found that $90 \%$ of patients knew that epilepsy was not a mental disorder, which was better than both the study and control group in our study. ${ }^{12}$

Approximately $81 \%$ of patients ( $n=164)$ knew that epilepsy was not hereditary in the study group as compared with only 93 patients in the control group (46.5\%) which was almost half of the study group. Our findings were consistent with that of Chandigarh, ${ }^{13}$ Kerala by Radhakrishnan et $a l,{ }^{4}$ and in Italy. ${ }^{14}$ The studies done in Nepal, Malaysia, and Canada found that there were more people (almost 50-60\%) who believed epilepsy to be hereditary. ${ }^{6,12,15}$ However, a study done in Delhi showed a more favorable result as $97 \%$ persons with epilepsy (PWE) considered that epilepsy was not hereditary. ${ }^{5}$

In our study, $70 \%$ of patients with epilepsy knew that epilepsy was not due to supernatural powers. In the control group, $50 \%$ believed the same. Similar were the findings in the studies done by Gourie Devi et al, Radhakrishnan et al, and Surekha and Surekha., ${ }^{4,8}$ In our study, we found that $80 \%$ of PWE believed that epilepsy was not contagious. However, studies done in Nepal and Nigeria found a considerable number of people (40-70\%) who believed that epilepsy was contagious. ${ }^{15,16}$ PWE are expected to know better about their disease, and this was consistent with what was found in our study and a study done in Kerala. ${ }^{17}$

Only 66\% of PWE in our study knew that epilepsy was not due to previous sins of patients or ancestors. The number was even lower in the control group where only 50\% knew this. This number was less than what was seen in Nepal (57.4\%), Kerala (85\%), and Chandigarh (95\%). ${ }^{4,13,15}$ However, only $75 \%$ of PWE in Delhi knew that epilepsy was not due to prior sins. ${ }^{5}$

Our study showed that almost $90 \%$ of people in both study and control groups knew that epilepsy was treatable by modern drugs, but still only 40\% PWE and even lesser numbers (13\%) in the control group knew that ayurvedic medicines were not helpful in epilepsy. This finding was almost similar to that of the study in Nepal where $85 \%$ of people trusted allopathic treatment. ${ }^{5}$ However, PWE in Delhi were more informed about treatment as $90 \%$ believed in allopathy. ${ }^{5}$ As far as ayurvedic drugs were concerned, more people in Kerala and Nepal believed that ayurvedic treatment was helpful as compared with PWE in our study.,15 However, if the control group of our study is seen, this number was more as compared with Kerala and Nepal. People believing in Ayurveda as a treatment for epilepsy was less in PWE of Delhi as compared with our study. ${ }^{5}$ In Chandigarh, the general population knew ayurvedic treatment similar to PWE of our study. ${ }^{5}$

As far as faith healers and sorcery as a treatment of epilepsy is concerned, $73.6 \%$ of patients in our study group and $62 \%$ in the control group knew that it was not helpful. This number was almost similar to the findings in Kerala. ${ }^{4}$ The PWE of Delhi (80\%) were more aware in this context than PWE in our study. ${ }^{5}$ A study done in Northwest India by Surekha and Surekha found $26.4 \%$ believed that faith healers were helpful in epilepsy treatment, which after 4 years of intervention in form of providing information about epilepsy with the help of video material, books, and charts decreased to $11.2 \%$, showing that improving knowledge about this disease may help to alleviate misconceptions about epilepsy. ${ }^{8}$

In our study, $78 \%$ of the PWE thought that they could study which was lower as compared with that in the control group in which $92 \%$ of people thought similarly. Our findings were similar to what was found among PWE in Delhi. ${ }^{5}$ However, in Saudi and Riyadh, more people thought that these patients have normal intelligence. ${ }^{18}$ Even in Chandigarh, 63\%, people thought that PWE should go to school regularly, and only $9 \%$ believed that their school should be changed. ${ }^{13}$

We found that $81 \%$ of PWE would allow their children to play with an epilepsy patient. This number was lower 
Table 5 Response of epileptic patients in rural and urban area

\begin{tabular}{|c|c|c|c|c|c|c|c|}
\hline \multirow[t]{2}{*}{ Questions } & \multicolumn{3}{|c|}{ Urban patients } & \multicolumn{3}{|c|}{ Rural patients } & \multirow{2}{*}{$\begin{array}{l}\text { Chi-square score } \\
p \text {-Value at } 0.05 \text { level } \\
\text { of significance }\end{array}$} \\
\hline & Yes & No & Do not know & Yes & No & Do not know & \\
\hline Have you heard about epilepsy? & 64 & 3 & 0 & 129 & 4 & 0 & $\begin{array}{l}\chi^{2}=0.2851 \\
p=0.5933\end{array}$ \\
\hline Is epilepsy a brain disorder? & 61 & 4 & 2 & 115 & 12 & 7 & $\begin{array}{l}\chi^{2}=1.1392 \\
p=0.56575\end{array}$ \\
\hline Is epilepsy a mental disease? & 8 & 54 & 5 & 12 & 109 & 13 & $\begin{array}{l}\chi^{2}=0.6531 \\
p=0.7214\end{array}$ \\
\hline Is epilepsy a hereditary disorder? & 9 & 55 & 3 & 17 & 109 & 8 & $\begin{array}{l}\chi^{2}=0.2041 \\
p=0.902985\end{array}$ \\
\hline $\begin{array}{l}\text { Is epilepsy due to supernatural } \\
\text { powers? }\end{array}$ & 19 & 47 & 1 & 38 & 96 & 1 & $\begin{array}{l}\chi^{2}=0.2535 \\
p=0.880945\end{array}$ \\
\hline Is epilepsy contagious? & 6 & 57 & 4 & 20 & 104 & 10 & $\begin{array}{l}\chi^{2}=1.6842 \\
p=0.4308\end{array}$ \\
\hline $\begin{array}{l}\text { Is it due to sins of patient/ } \\
\text { ancestors? }\end{array}$ & 19 & 47 & 1 & 44 & 86 & 4 & $\begin{array}{l}\chi^{2}=0.9263 \\
p=0.6292\end{array}$ \\
\hline $\begin{array}{l}\text { Is epilepsy treatable with modern } \\
\text { drugs? }\end{array}$ & 60 & 4 & 3 & 119 & 13 & 2 & $\begin{array}{l}\chi^{2}=2.331 \\
p=0.3106\end{array}$ \\
\hline $\begin{array}{l}\text { Is epilepsy treatable with Ayurvedic } \\
\text { medicine? }\end{array}$ & 24 & 32 & 11 & 66 & 49 & 19 & $\begin{array}{l}\chi^{2}=3.3381 \\
p=0.188352\end{array}$ \\
\hline Can faith healers treat epilepsy? & 11 & 48 & 8 & 24 & 101 & 9 & $\begin{array}{l}\chi^{2}=1.5822 \\
p=0.45343\end{array}$ \\
\hline $\begin{array}{l}\text { During an epileptic attack will you } \\
\text { put keys in the hands of patients? }\end{array}$ & 12 & 54 & 1 & 28 & 103 & 3 & $\begin{array}{l}\chi^{2}=0.4046 \\
p=0.816843\end{array}$ \\
\hline $\begin{array}{l}\text { During an epileptic attack will you } \\
\text { make the patient smell a shoe? }\end{array}$ & 20 & 46 & 1 & 46 & 87 & 1 & $\begin{array}{l}\chi^{2}=0.6167 \\
p=0.73465\end{array}$ \\
\hline $\begin{array}{l}\text { During an epileptic attack will you } \\
\text { take the patient to hospital? }\end{array}$ & 65 & 2 & 0 & 128 & 6 & 0 & $\begin{array}{l}\chi^{2}=0.2604 \\
p=0.609871\end{array}$ \\
\hline Can a child with epilepsy study? & 54 & 12 & 1 & 102 & 30 & 2 & $\begin{array}{l}\chi^{2}=0.544 \\
p=0.761871\end{array}$ \\
\hline $\begin{array}{l}\text { Will you allow your child to play } \\
\text { with a child with epilepsy? }\end{array}$ & 54 & 13 & 0 & 110 & 24 & 0 & $\begin{array}{l}\chi^{2}=0.0622 \\
p=0.79687\end{array}$ \\
\hline $\begin{array}{l}\text { Is the child discriminated by } \\
\text { batch-mates? }\end{array}$ & 33 & 33 & 1 & 69 & 61 & 4 & $\begin{array}{l}\chi^{2}=0.5771 \\
p=0.749351\end{array}$ \\
\hline $\begin{array}{l}\text { Is the child discriminated by } \\
\text { teachers? }\end{array}$ & 15 & 50 & 2 & 45 & 84 & 5 & $\begin{array}{l}\chi^{2}=2.9017 \\
p=0.2343\end{array}$ \\
\hline $\begin{array}{l}\text { Can a child with epilepsy play } \\
\text { games? }\end{array}$ & 63 & 4 & 0 & 123 & 11 & 0 & $\begin{array}{l}\chi^{2}=0.3242 \\
p=0.56909\end{array}$ \\
\hline $\begin{array}{l}\text { Can a person with epilepsy take } \\
\text { up a job? }\end{array}$ & 57 & 9 & 1 & 118 & 15 & 1 & $\begin{array}{l}\chi^{2}=0.4832 \\
p=0.78536\end{array}$ \\
\hline Can a person with epilepsy marry? & 61 & 3 & 3 & 127 & 6 & 1 & $\begin{array}{l}\chi^{2}=3.1915 \\
p=0.202757\end{array}$ \\
\hline $\begin{array}{l}\text { Will you reveal about the epilepsy } \\
\text { of your daughter before marriage? }\end{array}$ & 29 & 37 & 1 & 55 & 77 & 2 & $\begin{array}{l}\chi^{2}=0.093 \\
p=0.95453\end{array}$ \\
\hline $\begin{array}{l}\text { Will you reveal about the epilepsy } \\
\text { of your son before marriage? }\end{array}$ & 29 & 37 & 1 & 62 & 70 & 2 & $\begin{array}{l}\chi^{2}=0.1627 \\
p=0.921881\end{array}$ \\
\hline $\begin{array}{l}\text { Can a person with epilepsy have } \\
\text { children? }\end{array}$ & 55 & 4 & 8 & 119 & 6 & 9 & $\begin{array}{l}\chi^{2}=1.8739 \\
p=0.391814\end{array}$ \\
\hline Are you discriminated by spouse? & 19 & 32 & 16 & 21 & 87 & 26 & $\begin{array}{l}\chi^{2}=6.2638 \\
p=0.43636\end{array}$ \\
\hline Is branding useful in epilepsy? & 2 & 47 & 18 & 7 & 103 & 24 & $\begin{array}{l}\chi^{2}=0.4843 \\
p=0.288765\end{array}$ \\
\hline
\end{tabular}

in the control group. In a study done in Delhi among PWE, this number was considerably higher (95\%) showing a better attitude. ${ }^{5}$ In our study, almost $50 \%$ of the patients with epilepsy felt that they were discriminated by their batchmates. This number was lower in the control group (33\%). More PWE felt discriminated in our study as compared 
with the control group showing that there was some level of discrimination existing in the society toward epilepsy patients. A study in Bundelkhand also showed a similar finding where $53 \%$ of people thought that society should behave differently with PWE. ${ }^{9}$ Almost $73 \%$ of people in a study in Nepal felt that patients with epilepsy should not be discriminated against and did not object sitting next to them or playing with them..$^{15}$ The findings seen in the Nepal study and study by Radhakrishnan et al, were almost similar to our study. ${ }^{4}$

We found in our study that both in the study and control groups, $90 \%$ of people believed that these patients could play games and take part in sports. Our findings were similar to the study by Gourie Devi et al. ${ }^{5}$ The attitude of people toward PWE was better in our study in this context as compared with the study done in Bundelkhand in which $20 \%$ people thought that these patients could not play. ${ }^{9}$ The attitude was found even worse in Kerala as studied by Radhakrishnan et al, ${ }^{4}$ and in Malaysia in which almost $40 \%$ of people believed that these patients could not participate in sports. ${ }^{6}$

Patients with epilepsy face discrimination even on the employment front. In our study, the outlook was significantly better among PWE, as approximately $88 \%$ thought that they could do jobs normally as compared with $79 \%$ controls. In Delhi, also the findings were similar. ${ }^{5}$ The attitude was worse in Chandigarh and Kerala as 30 to $40 \%$ of people believed that patients with epilepsy should leave the job and normal people avoided giving a job to PWE. ${ }^{4,13}$ In Bundelkhand, it was even worse, as approximately $65 \%$ of people thought that PWE could not work normally. ${ }^{9}$ Attitude toward employment for PWE was similar to our study in Canada where $90 \%$ of people thought that these patients could do the same jobs such as people without epilepsy. ${ }^{12}$ However, still the attitude score in this study, attitude toward employment had the lowest score. This finding was similar to that found in Hungary. ${ }^{19}$

Misconceptions regarding marriage and begetting children also exist regarding PWE. In our study, almost $94 \%$ of PWE thought that they can marry. This number was less in the control group (85\%). Our findings were similar to the findings of Gourie Devi et al in Delhi. ${ }^{5}$ As far as begetting children is concerned $85 \%$ of patients of epilepsy in our study thought that patients with epilepsy can have children. This number was a little less in the control group. Our findings were similar to studies done in Delhi in which almost 90\% thought that these patients could have children. ${ }^{5}$ The attitude regarding marriage and having children was worse in Bundelkhand in which only $70 \%$ of people thought that epilepsy patients could live a happy-married life. ${ }^{9}$ Similar were the findings in Malaysia and Nepal. ${ }^{6,15}$ Only 30 to $40 \%$ of people in Kerala and Bundelkhand thought that epilepsy patients could have a normal sexual life, according to the studies, which was lower than our study. ${ }^{4,9}$ However, in our study, people did not object to the marriage of epilepsy patients but still discrimination existed as many people wanted to hide the epilepsy condition of their son or daughter before marriage. In our study, $42 \%$ of patients from the study group were ready to reveal the epilepsy of their daughters before marriage. This number was lower in the control group (25\%). Similarly, almost $45 \%$ of people wanted to reveal the epilepsy of their son before marriage. This number was lower than the PWE in Delhi (60\%). ${ }^{5}$ From our study, we can see that patients with epilepsy still face discrimination in the fields of education, employment, and marriage, and there is a significant difference in the attitude toward epilepsy between patients with epilepsy and without epilepsy; the attitude being more positive in the PWE due to better knowledge about the disease in these patients.

Malpractices regarding epilepsy are prevalent in the world. Instead of providing first aid, such as proper positioning of a seizing patient, protecting his head, and taking him away from potential hazard, practices such as placing a bunch of keys in the hands of the patient, sprinkling water on his face, and making him smell a shoe, that can harm him during the seizure are still prevalent. In our study, $80 \%$ of PWE knew that placing keys in the hands of the seizing patients was not helpful. This number was lower in the control group in which only $66 \%$ of people knew this. In Delhi's study by Gourie Devi et al, among PWE, 93\% of people knew to place keys in the hands of seizing patients was useless. ${ }^{5}$ This practice was also advocated in 20 to 25\% of people in studies done in Bundelkhand and Nepal, which was similar to our study. ${ }^{9,15}$ This number was higher in the study by Radhakrishnan et al in Kerala in which $55 \%$ of people thought that such practice was helpful. ${ }^{4}$ Another prevalent practice is to make a seizing patient smell a shoe. In our study, $67 \%$ PWE and $58 \%$ people of the control group knew that this was not helpful. This number was lower than what was found among PWE in Delhi and people visiting Rani Laxmibai Medical College in Bundelkhand. ${ }^{5,9}$ Other practices that were prevalent as seen in other studies were sprinkling water on the face of the seizing patient, putting fingers or clothes in their mouths, lightening a matchstick, etc. In spite of all these malpractices, $96 \%$ of the people in our study in both groups thought that taking a seizing patient to the hospital was necessary, which was similar to the findings by Gourie Devi et al, and was better than the findings of studies done in Kerala, ${ }^{4}$ Chandigarh, and Nepal. ${ }^{4,5,13,15}$ Poor first aid response was found in studies done in Kerala by Radhakrishnan et al. ${ }^{4}$

In our study, $75 \%$ of PWE and $60 \%$ people of the control group agreed that branding was useless in epilepsy. However, this number was quite low as compared with the findings of Gourie Devi et al in Delhi among PWE. ${ }^{5}$ Malpractices are still prevalent among people regarding what is to be done to help a seizing patient. However, one positive practice seen was that almost everyone agreed on to take such a patient to a hospital. Educating the general population about the measures that should be taken, when they see a seizing patient, is necessary to improve the quality of first aid given to such patients.

\section{Conclusion}

It can be stated that poor knowledge, negative attitude, and malpractices are still prevalent in India, which can 
be attributed to low awareness about epilepsy among the masses. It was found in our study that PWE have better KAPs toward epilepsy as compared with people without epilepsy which may be attributed to better awareness about the disease among the sufferers. Male gender was associated with a better attitude as compared with the female gender. Better education was also associated with better KAPs. However, there is still a need to improve awareness about epilepsy to curb the negative attitude and poor practices prevalent about this disease among the masses and improve the quality of life of PWE.

\section{Funding}

This study was supported by the IMS-BHU.

\section{Conflict of interest}

None declared.

\section{References}

1 Fisher RS, van Emde Boas W, Blume W, et al. Epileptic seizures and epilepsy: definitions proposed by the International League Against Epilepsy (ILAE) and the International Bureau for Epilepsy (IBE). Epilepsia 2005;46(4):470-472

2 WHO. Atlas: Epilepsy Care in the World. Geneva, Switzerland: World Health Organization; 2005:8

3 Rao MB. Addressing the burden of epilepsy in India.... Neurol India 2017;65(Supplement):S4-S5

4 Radhakrishnan K, Pandian JD, Santhoshkumar T, et al. Prevalence, knowledge, attitude, and practice of epilepsy in Kerala, South India. Epilepsia 2000;41(8):1027-1035

5 Gourie Devi M, Singh V, Bala K. Knowledge attitude and practice among patients of epilepsy attending tertiary care hospital in Delhi, India and review of Indian studies. Neurol Asia 2010;15(3):225-232

6 Neni SW, Latif AZ, Wong SY, Lua PL. Awareness, knowledge and attitudes towards epilepsy among rural populations in East Coast Peninsular Malaysia: a preliminary exploration. Seizure 2010;19(5):280-290
7 Hasan SS, Wei W, Ahmadi K, Ahmed IS, Yong AKS, Anwar M. Knowledge and attitudes toward epilepsy among Malaysian Chinese. International Journal of Collaborative Research on Internal Medicine \& Public Health 2010;2(11):361-376

8 Surekha AK, Surekha R. Knowledge attitude and practice with regards to epilepsy inrural north west India. Ann Indian Acad Neurol 2007;10(3):160-164

9 Kankane AK, Kankane A, Siddiqui MZ, Mishra P. Knowledge, attitude and practice of epilepsy among persons attending tertiary care hospital of Bundelkhand region, Central India. Indian J Community Health 2015;27(2):281-285

10 Long L, Reeves AL, Moore JL, Roach J, Pickering CT. An assessment of epilepsy patients' knowledge of their disorder. Epilepsia 2000;41(6):727-731

11 Ezeala-Adikaibe BA, Achor JU, Nwabueze AC, et al. Knowledge, attitude and practice of epilepsy among community residents in Enugu, South East Nigeria. Seizure 2014;23(10):882-888

12 Young GB, Derry P, Hutchinson I, et al. An epilepsy questionnaire study of knowledge and attitudes in Canadian college students. Epilepsia 2002;43(6):652-658

13 Goel S, Singh N, Lal V, Singh A. Knowledge, attitude and practices of students about first aid epilepsy seizures management in a Northern Indian City. Ann Indian Acad Neurol 2013;16(4):538-543

14 Mecarelli O, Li Voti P, Vanacore N, et al. A questionnaire study on knowledge of and attitudes toward epilepsy in schoolchildren and university students in Rome, Italy. Seizure 2007;16(4):313-319

15 Thapa L, Bhandari TR, Shrestha S, Poudel RS. Knowledge, beliefs, and practices on epilepsy among high school students of central Nepal. Epilepsy Res Treat 2017;2017:6705807

16 Teferi J, Shewangizaw Z. Assessment of knowledge, attitude, and practice related to epilepsy: a community-based study. Neuropsychiatr Dis Treat 2015;2015:1239-1246

17 Kuriakose S, James E, Kumar A. Assessment of knowledge of epilepsy in epileptic patients attending a tertiary care centre in Kerala, India. Int J Pharm Pharm Sci 2014;6(7):64-67

18 Abo GM, Shahbo EM, Bharathi B, Daoala AL. A comparative study on knowledge, attitudes and beliefs of epilepsy among communities of Egypt and Kingdom of Saudi Arabia. IOSR J Nurs Health Sci 2014;3(5):97-107 